\title{
CHILD SUPPORT - SUPPORTING WHOM?
}

\author{
Bill Atkin and Andrew Black
}

The Child Support Act 1991 has been a highly controversial piece of legislation. While much of the public consternation has quietened, questions should still be asked about the scheme. To what extent are children and caregivers gaining anything substantial? Given the State's vested interest in recouping for itself some of the cost of social security benefits, whom does child support really support? The authors note the dearth of research on the effectiveness of the scheme in achieving its goals. This article also discusses the narrow views of parental and financial responsibility enshrined in the Act and reinforced by unduly restrictive Court of Appeal rulings.

\section{INTRODUCTION}

The Child Support Act 1991 was introduced to rectify apparent inequities faced by parents caring for children without the immediate financial support of the other parent. This is purportedly done by using a formulaic assessment of the non-custodial (liable) parent's income to determine how much that person should pay. Although the current system appears to be working more efficiently ${ }^{1}$ than the previous schemes, ${ }^{2}$ there are still large question marks over whether this Act is in fact the best that we can do for children and families.

The focus of the current legislation is the financial support of the child, not the best interests of the child. The authors ask whether more is necessary in relation to the social aspects of child rearing. To what extent does the child support scheme help to stop the cycle of poverty that appears to be becoming predominant among single parent children? To what extent does it set incentives in place which do not necessarily help families and

* Reader in Law and Research Assistant, Victoria University of Wellington.

1 Measuring efficiency in purely administrative terms as there are areas where, for example, private agreements can offer a lot more flexibility.

2 Prior to the Child Support Act 1991 two schemes were in place. The first operated where the custodian was a beneficiary and was called the Liable Parent Contribution Scheme, and the second was the making of a maintenance order or agreement when the custodian was not a beneficiary. 
children? How does it really benefit children and their caregivers? Does it help the noncustodial parent take an active parenting role with the child? These key questions are alluded to in the present paper. Further research on them is urgent.

This paper also focuses on the departure order provisions contained in the legislation. The authors suggest that the approach of the Court of Appeal has been unduly restrictive.

\section{CONTROVERSIAL LEGISLATION}

The Child Support Act 1991 has been in force for over six years. It has been one of the most controversial pieces of legislation passed this decade. ${ }^{3}$ It was riddled with mistakes and it has been reviewed more than once. A high powered committee headed by a former Principal Family Court Judge considered that fundamental changes were required, ${ }^{4}$ but these have not been implemented. The so-called Trapski Report appears to have been shelved.

Public consternation over the Act has quietened. One reason for this is that many contentious situations, created when the scheme first came into operation as a result of the Act's retrospective effect, have now passed. People are, we presume, re-organising their lives according to the formula contained in the Act. A further reason is that, whereas a person seeking a "departure" from the formula was forced to go to court under the original legislation, new procedures for obtaining a departure by means of an internal review by the Commissioner of Inland Revenue ${ }^{5}$ were, somewhat as an afterthought, introduced in $1994 .{ }^{6}$ These have simplified and reduced the cost of challenging child support assessments, but the new procedures still take place against the shadow of the law as interpreted by the courts. In the early days of child support, thousands of cases went through the judicial system, a significant number going on appeal to the High Court and the Court of Appeal. The rules laid down by these courts have been strict, showing little of the flexibility and humanity normally associated with family law cases.

3 For a discussion of the first year of the history of the scheme, see B Atkin "Child Support Update Problems Persist" (1993) 1 BFLJ 52.

4 Peter Trapski, Diana Halsted, June McCabe, Tony Walsh "Child Support Review 1994: Report of the Working Party" 8 November 1994 (The Trapski Report).

5 The Inland Revenue Department is the government department responsible for the Child Support Act. This function is carried out by Inland Revenue Child Support formerly called the Child Support Agency. In practice the review of departure applications is carried out by specially appointed review officers.

6 Child Support Act 1991, ss 96A - 96P. 
Public controversy about child support is not unique to New Zealand. The English Act, passed in the same year as the New Zealand one but implemented in 1993, was the subject of a Government White Paper in 1995 and another Green Paper in 1998, entitled "Children First - a new approach to child support". ${ }^{7}$ To illustrate the failure of the English scheme, the Prime Minister in the Foreword to the Green Paper asserts that "the Child Support Agency has lost the confidence of the public". By contrast the Australian Act (which provided much of the template for the New Zealand Act) fared rather better with its legislation. ${ }^{8}$ Australia did not make its scheme retrospective, thus avoiding the unravelling of carefully worked out arrangements which may have been in place between parents for many years. In the New Zealand context, it is not surprising that emotions ran high when, for example, a custodial parent suddenly found that the amount she was entitled to receive from the other parent plummeted from $\$ 520$ per month to $\$ 43.35,{ }^{9}$ or a liable parent saw his obligation sky-rocket from $\$ 40$ per month to $\$ 675 .{ }^{10}$

\section{NOW RUNNING SMOOTHLY?}

In many ways, the child support scheme now seems to be running smoothly. The current collection rate of assessed amounts for the year to 31 March 1998 is reported to be $76 \%$, a vast improvement over previous systems which hovered below $50 \% .{ }^{11}$ The amount collected over all years since the scheme has been operating is $93 \%$, suggesting that the recovery of arrears is achieved with considerable efficiency. The number of cases being contested in the courts has also dropped away. Between 1 April 1997 and 31 March 1998, only eighteen applicants applied to the Family Court for a departure order, having been denied one by the review officers, and, of these, thirteen were also denied by the Court.

On the other hand, a considerable number of departure applications were handled by review officers between the inception of the review process in 1994 and March 1998. Of 3183 applications, $34 \%$ were from custodial parents with $53 \%$ being successful. Of the 2088 applications by liable parents $31 \%$ were successful. These figures, though relatively small when put alongside the total of 181,000 custodians and 134,000 liable persons (at

7 Cm 3992. For an upbeat discussion of this latest paper, see Chris Barton "Third Time Lucky for Child Support? - The 1998 Green Paper" [1998] Family Law 668.

8 Child Support (Assessment) Act 1989 (Cth).

9 Andrews $v$ Andrews [1995] NZFLR 769.

10 Lyon v Wilcox [1994] NZFLR 634.

11 Mark Henaghan and Bill Atkin Family Law Policy in New Zealand (Oxford University Press, Auckland, 1992) 213. 
the end of March 1998), indicate that for a minority of people, both payers and recipients, the child support formula is inappropriate.

One potential problem with the review procedure, seriously affecting the Family Court's jurisdiction, is where an upward departure order is granted in favour of the custodian, and the liable parent wishes to have the decision overturned (or vice versa, where a custodian wishes to challenge a downward departure which a review officer has granted to a liable parent). It appears that the challenger must resort to judicial review in the High Court. ${ }^{12}$ An unsuccessful applicant can apply to the Family Court for a departure order but there is no process in the Act for the respondent to appeal a successful application. ${ }^{13}$ Judge Ellis of the Family Court commented in Campbell v Campbell ${ }^{14}$ that:

Under the legislation as amended in 1994 which introduced the provisions for hearing by or on behalf of the Commissioner as a first step, the legislation deliberately has not included any right of appeal from such determination to this Court. It is therefore not open to a liable parent to appeal the findings nor exercise of discretion by the Commissioner, and any appeal or review of such decisions could only be by way of judicial review. Whether or not that was a deliberate intention of the legislation, it is not for me to speculate, but that is the effect of it. The opportunity for a second departure application clearly was deliberately created by the provisions of s 104 which make it clear that a party can only apply for a departure order in this Court if there has been a determination by the Commissioner and so there is a quite deliberate insertion there of a second tier of application to this Court. That of course is not by way of rehearing or review or appeal, but it must be by way of a fresh application to this Court which will also need to be supported by a statement of grounds.

There appears to be no good policy reason for forcing parties to make an application for judicial review and the present state of the law is probably the result of an oversight. The authors also understand that, despite the jurisdictional lacuna, the Commissioner has not challenged the respondent's standing in the Family Court when the respondent has used a departure order application in effect as an appeal mechanism. ${ }^{15}$ Be that as it may, the current state of the law is unsatisfactory and needs to be addressed by Parliament.

12 Brokenshire v Scott (13 April 1995) unreported, Family Court, Timaru Registry MFP 11/95.

13 Sections 100 - 103 of the Act allow a party to object to certain specified decisions of the Commissioner through an appeal process to the Family Court.

15 Respondents can, of course, seek a departure in their own right (as noted in the quote from Judge Ellis) but must have their own independent grounds and should go through a separate review process. 
Another factor to emerge from child support statistics is the very large number of liable persons paying the statutory minimum of $\$ 10$ per week. ${ }^{16}$ The $65 \%$ falling into this category are there because their taxable incomes are too low for the formula to demand more. Many are beneficiaries, probably unemployed, and often the custodian is also a beneficiary, in which case the $\$ 10$ will be paid to the State and not passed on to the custodian. ${ }^{17}$ What really happens is that a large bureaucracy is in place to ensure that there is a paper transaction shifting a small amount of money from one branch of government to another, unseen by the children and parents who ostensibly form the subject-matter of the transaction. Other minimum payers are low paid workers or else wealthier people who manage their finances so that they record low assessable income.

The big question which arises from all this is how well the system is actually treating the children and their carers for whom it is designed. Who is the child support scheme actually "supporting"? Are children better off because of this scheme? Are their parents better able to provide for them, especially when the vast majority of custodial parents do not see anything of the contribution made by the liable parent? Is it more "efficient" for the State but less effective for families and their members? What research has been done to establish whether it is really working and achieving its goals, and not merely being run in a business like manner? These important issues deserve full scale investigation.

\section{IV "PARENTAL" RESPONSIBILITY}

Other fundamental questions about child support also need to be asked. To a large extent the Child Support Act is about "responsibility". ${ }^{18}$ But what kind of responsibility is envisaged? First, it is "parental" responsibility, and this essentially means biological and adoptive (ie deemed biological) parenthood. Little recognition is given to the moral and social obligations of step, foster and whanau parenting. There are three main exceptions. An "eligible custodian" who is entitled to apply for child support need not be biologically related to the child, so long as that person is a principal caregiver of the child. ${ }^{19}$ Next,

16 Child Support Act 1991, s 72. In several judgments, Judge Inglis QC has floated the possibility of the court's having the power to reduce the obligation to $\$$ zero, a result achieved by consent order, with the acceptance of the Commissioner, in $O v H$ [1998] NZFLR 673 (although the liable parent, perhaps unnecessarily, conceded that the minimum amount still had to be paid).

17 Such "passing on" occurs in Australia and a 30\% level of "passing on" has had support in the past from the Labour Party: see (1994) 541 NZPD 2051 per Hon C Matthewson.

18 For an excellent exploration of this, see J Eekelaar "Parental Responsibility: State of Nature or Nature of the State?" [1991] JSWFL 37, discussed in the New Zealand context by B Atkin "Financial Support: The Bureaucratization of Personal Responsibility" in M Henaghan and B Atkin Family Law Policy in New Zealand (Oxford University Press, Auckland, 1992).

19 Child Support Act 1991, s 8. The Act also recognises the phenomenon of joint and shared custody: see especially s 13, and Johns $v$ CIR [1999] NZFLR 15. 
under the formula, the level of contribution is reduced by taking into account obligations to a maximum of four dependent children, including step and other children. ${ }^{20}$

The third exception deserves more extensive discussion. Under section 99, the Court can declare a person to be a "step-parent", thus making that person liable to pay child support. Two controversial decisions in 1998 have examined this rarely used provision. In BPS $v M N S,{ }^{21}$ the High Court was faced with a situation where a husband and wife had tried without success for a child through a regular donor insemination programme. Eventually the wife had a child after natural intercourse with a "donor". The marriage did not last and a year after separation, the husband gave up access to the child largely because of difficulties created by the mother. Extreme hostility between the two continued to persist to the date of hearing. DNA tests proved that the husband was not the father of the child, thus overturning the usual presumption that a husband is the father of his wife's child. ${ }^{22}$ Even though he had intended from the beginning to be the child's social parent, Doogue and Goddard JJ refused to declare the husband a stepparent. They noted that the husband had had contact with the child for only one and a half out of the child's seven years of life. They accepted the submission of counsel that the respondent was now not a parent to the child in any sense.

Given the long-term cessation of the relationship between the child and the husband, the result in BPS is probably the correct one. If however the artificial donor insemination programme had been successful, the result would have been totally different, for under the Status of Children Amendment Act 1987, the husband would have been deemed to be the legal father instead of the donor. We might well ask why the accident of the means of birth (natural intercourse rather than artificial insemination) should make such a radical difference, all other things about the relationship between the parties being the same. The judgment in BPS is instructive for other reasons. The judges stated: ${ }^{23}$

...it is accepted that revenue legislation requires a strict construction. However the objects of the Act, which centre on the rights of the child and the obligations of its parents, also colour the interpretative approach.

Although the welfare and interests of the child are, surprisingly, omitted from the aims of the Act - a point picked up by the Trapski Report ${ }^{24}$ - the Court in BPS was

20 Child Support Act 1991, s 30, the "living allowance".

21 [1998] NZFLR 289.

Status of Children Act 1969, s 5.

3 [1998] NZFLR 289, 294.

24 The Trapski Report, above n 4, 11; 77. The first recommendation was that the child's welfare be included in the "objects" of the Act. 
heavily influenced by the child's best interests and the social reality of lack of contact between the respondent and the child. A step-parent declaration was thought not to be in the child's best interests because it would resurrect the destructive nature of the relationship between the mother and the respondent - "any contact between them cannot possibly be of benefit to [the child]". ${ }^{25}$ The strong implication is that the Court envisaged the respondent having some real parental responsibility if declared a step-parent under section 99, an approach to responsibility and to interpretation of the Act noticeably lacking in the leading judgment of the Court of Appeal. ${ }^{26}$ The Court in BPS was concerned with what was really happening in people's lives, and how this should impact on the payment of child support. ${ }^{27}$

BPS was followed in $A v R,{ }^{28}$ with however a different outcome on the facts. Two adults had enjoyed a lesbian relationship from 1979 until 1993. One of them had three children by donor insemination, the lesbian partner acquiring some parental standing by being made an additional guardian under section 8 of the Guardianship Act 1968. An attempt to use the adoption laws had failed. ${ }^{29}$ The relationship terminated when the birth mother had a religious conversion and gave up her support of the lesbian network. ${ }^{30}$ Guardianship ceased in 1995 but in 1997 the birth mother sought a step-parent declaration. In the Family Court Judge Brown distinguished BPS primarily on the grounds that, compared with the short period of contact in BPS, the contact with and parenting of the child in $A v R$ had been very considerable, indicating that the respondent had accepted responsibility for the child: ${ }^{31}$

While I think that there was an element of the political (and of the conscious trail blazing) in the parties' legal decisions, they were decisions made within a 14 year relationship and to my mind they represent the most uncompromising acceptance of fiscal and other responsibility for

25 [1998] NZFLR 289, 295.

26 Lyon v Wilcox [1994] NZFLR 634.

27 A "realistic" approach to family arrangements can also be discerned in $O v H$ [1998] NZFLR 673, mentioned in footnote 16, above. Judge Inglis QC granted the \$zero consent order against a background of the exclusion of the father from access to the children, false allegations of sexual violation, and a planned step-parent adoption by the mother and her new husband.

28 [1999] NZFLR 249. The Family Court decision is reported as $T v T$ [1998] NZFLR 776.

29 Re an Application by T [1998] NZFLR 769 (judgment by Ellis J, 20 February 1992).

30 Interestingly, those facts are not mentioned in the High Court judgment, where the breakdown in the relationship is explained by the appellant's commencing a new relationship with another woman.

$31 \quad T$ v T [1998] NZFLR 776, 781. 
the children possible. Such decisions in my view are not to be vacated on the basis of later regret...

Judge Brown thought that "the entire circumstances" needed to be considered, accepting that concentration on the biological and financial aspects is too narrow a view. This decision was upheld on appeal by Penlington and Hammond JJ. The two judges had little difficulty in agreeing with Judge Brown's assessment of the facts, nor were they fazed by an argument that a lesbian could not be a step-parent. Somewhat alarmingly however was a further ruling that, in contrast to BPS, "there is no warrant, for importing, as a matter of principle, any 'welfare of the child' test into s 99(4)(a)."132 So, once again, we see the focus of the Court narrowing, underlining how out of step the Child Support Act is with fundamental family law and international principles. ${ }^{33}$

\section{FINANCIAL RESPONSIBILITY}

This leads to the second aspect of "responsibility" under the Child Support Act. The legislation is first and last about financial responsibility. ${ }^{34}$ It is designed to make parents pay for their children, irrespective of the nature of the relationship between the payer and the child (BPS, $A v R$ and $O v H$ being striking exceptions to this philosophy). It is not possible, for example, for the liable parent to say that there has (for many years) been no contact with the child, or that the custodial parent has made contact difficult or impossible, or that the parenting role has been willingly taken over by someone else. ${ }^{35}$ The obligation to pay money sticks by virtue of the biological link, no matter how obscure this link is in day to day terms. Legal reality and social reality can be utterly remote in the interests of enforcing the monetary obligation.

Turning this point around the other way, we find nothing in the child support régime which encourages the financial parent to become a real parent nor is there any incentive on the custodian to encourage the absent parent to become active in the child's life. And here lurks a genuine worry for the family law protagonist. Child support is isolated from

32 A v R [1999] NZFLR 249, 257.

33 Article 3 of the United Nations Convention on the Rights of the Child requires the child's best interests to be a primary consideration.

34 A point noted in $A v R$ [1999] NZFLR 249, 252: "The new scheme was substantially driven by fiscal concerns".

$35 O v H$ [1998] NZFLR 673, mentioned in footnotes 16 and 27, succeeded because of a sympathetic judge and because all the parties agreed. Would the result be the same if the custodian opposed the order? 
the other issues affecting the lives of children and their parents. Barton, writing in the English context, writes compellingly about this: ${ }^{36}$

An associated issue is the relationship, or rather the long-standing lack of one, between paying and seeing: the poker principle. This represents the most extreme example of how the 1990s' child support legislation diverts from the long path, otherwise maintained by both the Children Act 1989 and the Family Law Act 1996, towards an integrated approach to family breakup and re-formation.

Barton also quotes Dame Brenda Hale, eminent Family Division Judge, who said that "we have now separated the financial and caring responsibilities of parenthood, and I wonder how far this really serves the child's interests". ${ }^{37}$ In New Zealand, the establishment of the Family Court, along with the conciliation and mediation provisions of the Family Proceedings Act 1980, parallel the English legislation mentioned by Barton. These comments translate readily into the New Zealand landscape. Hammond J noted in $A v R^{38}$ that

Child support exists quite independently of contact with the children, or the nature of the post-

separation relationship between the partners.

In this postmodern age, it is unrealistic to try and find a seamless thread running through the whole of family law but some broad underlying principles such as the welfare of the child, and the encouragement of parties to reach their own solutions and to work amicably and responsibly together in the interests of their children, can still be advanced. The child support legislation has however removed one of the major items of the parenting package from the arena. In so doing, it has rendered the quest for an overall family policy forlorn. Whether it has actually caused distress and harm to the affected children and parents, or on the contrary has benefited them, can only be determined when the relevant research is undertaken. That research is urgently called for.

36 Chris Barton "Third Time Lucky for Child Support? - The 1998 Green Paper" [1998] Family Law 668,669 .

37 The Rt Hon Mrs Justice Hale "The eighth ASARCO annual lecture 1997: Private lives and public duties: What is family law for?" (1998) 20 JSWFL 125, 132. Hale J has written earlier works under the name of Brenda Hoggett.

38 [1999] NZFLR 249, 258. 


\section{LYON VWILCOX}

The leading case on the Child Support Act 1991 is the Court of Appeal decision in Lyon $v$ Wilcox $^{39}$ and it represents, it is submitted, the narrow parental and financial responsibility philosophy just outlined, with little recognition given to social facts. The case arose out of a departure application brought by the liable parent, who had seen his court-ordered maintenance rise nearly sixteenfold after the child support régime was brought into operation.

The central rules for departure orders are found in section 105 of the Child Support Act 1991. This provision is, in the words of the Court of Appeal, one "of formidable complexity" ${ }^{40}$ for which we have to thank an Australian draftsperson whose convoluted language was unwisely copied in New Zealand. ${ }^{41}$ It is not intended to examine section 105 comprehensively, ${ }^{42}$ but in summary, the hurdles an applicant must surmount might be described as follows:

(a) The applicant must show that there is a ground for a departure order. Depending on how they are counted, there are at least nine such grounds, some of which relate to the applicant's own circumstances, some to those of the respondent, and others to those of the child. For the purposes of the present discussion, we should note the ground contained in section 105(2)(c)(i): "The income, earning capacity, property and financial resources of either parent or the child" render the formula assessment "unjust and inequitable". Another way of putting this is to say that a comparison of the parties' overall financial positions calls for an assessment different from that produced by the child support formula.

(b) The applicant, in establishing a ground for departure, must also convince the court that there are "special circumstances". In some cases, the ground must be "by virtue of special circumstances", in others "in the special circumstances of the case". The ground contained in section 105(2)(c)(i) must be "by virtue of special circumstances". In Re $M_{1}^{43}$ an early and seminal High Court judgment which set the tone of most of the later jurisprudence, Eichelbaum CJ and Heron J considered

39 [1994] NZFLR 634.

$40 \quad$ Lyon v Wilcox [1994] NZFLR 634, 638.

41 England avoided this problem by omitting a departure procedure entirely. Such an omission became however a point of criticism of the English scheme.

42 For this, see Butterworths Family Law Service (loose-leaf, Wellington) para 5.232 (updated March 1999).

43 [1993] NZFLR 74, 83. 
that the difference in language was of no consequence and was "no more than a vagary of draughtsmanship". It is commonly accepted however that the terminology means that "those seeking departure must pass through a narrow gate $^{\prime \prime 4}$ and must show facts which set their case apart from others.

(c) The applicant, having established an appropriate ground, must convince the court that a departure order would be just and equitable. The factors relevant to this enquiry are set out in subsection (4).

(d) The applicant must convince the court that a departure order would be "otherwise proper". While the Australian Act explains what this vague phrase means, ${ }^{45}$ the New Zealand Act is silent, leaving scope for all manner of argument. One of the leading decisions on the point, CIR $v$ Cutbush ${ }^{46}$ is, with respect, bizarre. A liable parent had perfectly adequately satisfied (a), (b) and (c) above and on the face of it deserved some relief from the formula. Blanchard J however decided that an order was not "otherwise proper" because the applicant could afford to pay the full amount. This is curious because it means that justice and equity are trumped by the ability to pay, surely not the intention of the departure procedures. The ruling may be restricted to the situation where the custodian is a social security beneficiary as Blanchard J had the "burden" on the taxpayer in mind, ${ }^{47}$ yet the judgment is not expressly limited in its scope and arguably a submission about ability to pay should apply just as much, if not more so, where the money is going directly to the custodian and children. The Act, after all, is primarily supposed to be about support of children, not about support of the taxpayer.

This picture of the departure rules is a simplification, but for the purposes of discussing Lyon $v$ Wilcox, another complication has to be introduced. Under subsection (5), the financial position of the custodian's new partner, if the custodian has one, must be ignored unless one of three conditions is met:

(i) that partner has a duty to maintain the child,

(ii) is a party to the proceedings, or

(iii) more importantly, "in the special circumstances of the case, the Court considers that it is appropriate".

\footnotetext{
44 Lyon v Wilcox [1994] NZFLR 634, 643.

45 Child Support (Assessment) Act 1989 (Cth), s 117(5).

46 [1994] NZFLR 598.

47 [1994] NZFLR 598, 605.
} 
The facts of Lyon $v$ Wilcox were unusual. ${ }^{48}$ The parents of the child in question had had a relationship but had not lived together. The child, born in 1979, was conceived when the mother, Ms Lyon, failed to use contraception as planned. The couple proposed to have the child adopted but the mother did not proceed with this. The mother and child moved to Scotland and the mother married Mr Arlidge who, by the time of the hearing, had acted de facto as the boy's father for at least eight years. Both Mr Arlidge and Ms Lyon were in paid employment. Mr Wilcox, the biological father, had had nothing to do with the boy since his birth and no one suggested that he should have. He had however since the boy's birth been paying child maintenance as ordered by the court at the level of $\$ 10$ per week. Under the child support formula, he was required to pay significantly more, viz \$156 per week. He was in full-time employment and, prior to the child support scheme's coming into force, he had bought a house with a heavy mortgage. To summarise, Mr Wilcox was a "financial" parent and nothing more. He had less to do with the child than the respondent in BPS $v$ MNS, discussed above. ${ }^{49}$ The social reality was that the boy's "real" parents and family were Ms Lyon and Mr Arlidge, all living in Scotland. Mr Wilcox did not deny some responsibility for the child - the question was the extent of this responsibility. In answering this question, should the court look at the social facts and weigh up the overall circumstances of the parties? Broadly speaking, the Court of Appeal said no.

The relevant ground for departure was section 105(2)(c)(i), ie the respective financial positions of the parties. The critical ruling of the Court is found in these words: ${ }^{50}$

When it comes to establishing a ground for a departure order under subs (2)(c) the focus is on economic considerations and it follows that only matters of this kind are relevant to deciding what is just and equitable, and what constitute special circumstances.

This unduly narrow reading, not warranted it is submitted on the express wording of the subsection, enabled to Court to ignore the special features of the child's birth, the child's subsequent history, and the liability of a New Zealand resident for a child living in Scotland. Yet, this was crucial in the liable parent's financial decision-making. The decision to purchase a house was made at least in part on the known basis of ongoing child maintenance obligations. Given all the circumstances, the liable parent made that decision confidently but, as it transpired, misguidedly, relying on mutually understood

48 The authors are concentrating on certain aspects of the case. We omit some other issues such as the liable parent's responsibilities to another son aged 22, and to elderly parents in the United States.

49 [1998] NZFLR 289. See Part IV. The same comparison can be made with $O v H$ [1998] NZFLR 673, also discussed in Part IV.

50 [1994] NZFLR 634, 645. 
expectations. In other words, to limit "special circumstances" as the Court did meant that only part of the story was legally relevant. Yet the missing part inevitably impacted upon the liable parent's financial commitments.

A narrow interpretation of the Act also dominated the Court of Appeal's attitude to the question of the relevance of Ms Lyon's husband's income under section 105(5). Include this income and her need for child support diminished. Exclude it and, on a comparison of the parties' respective financial positions, the liable parent's case was much weaker. In the High Court, Tipping J made a mistake in suggesting that it was not necessary to show special circumstances under subsection (5). ${ }^{51}$ It is quite clear however that Tipping J thought that there were special circumstances in this case and listed 16 of them. The Court of Appeal held that only one was relevant to subsection (5), viz the fact that $\mathrm{Mr}$ Arlidge had acted de facto as the boy's father for 8 years, but this circumstance, the Court held, was not special enough. ${ }^{52}$ The social and financial reality of the boy's life was therefore to be ignored. This interpretation is not compelling. Subsection (5) is not restricted in its language. In the usual situation, the custodian's spouse's income is not to be taken into account, but the court is nevertheless invited to consider whether it is appropriate to do so. The boy's current living arrangements, the unusual history of his conception and subsequent upbringing are surely highly relevant to the questions of appropriateness and whether the situation is unusual. They help explain why the liable parent had not had contact with the boy and why Mr Arlidge had taken over the parental role. They also inform us that this was not an average step-parent situation where the father's financial commitment mirrors some ongoing involvement in the child's life. Why the Court of Appeal allowed only one fact to be picked out is simply not explained. The Court mentioned two possible situations where subsection (5) might be satisfied - "if $\mathrm{Mr}$ Arlidge had been a wealthy man, or had refused to allow Mr Wilcox to make payment for Heath". These exceptions are entirely consistent with the dominating motif of the judgment - they both turn on money to the exclusion of the human relations aspects of the story.

The result of the Court of Appeal's ruling on subsection (5) was that Mr Arlidge's income was excluded from consideration, rendering the argument for a departure order very difficult. It reinforces a strict notion of parental and financial responsibility and ignores the true circumstances that this boy and many other children find themselves in

51 Wilcox v Lyon [1993] NZFLR 716, 724.

52 [1994] NZFLR 634, 645. 
today. Injustice may well occur as a result. The point of principle at stake here is well summarised by two of the world's leading socio-legal researchers: ${ }^{53}$

It is difficult for a formula-based system to allocate the direct support obligation between a child's parents fairly. It would need to take into account a wide range of circumstances, such as the extent to which the absent parent had already made provision in the form of capital and property settlement or makes provision in other forms, perhaps including expenses incurred in keeping contact with the child; and whether the carer had acquired other means of support (for example, from a new partner); and whether the absent parent's legal obligation conflicted with new familial obligations (social or legal) he may have acquired. The reason is that a child is a member of a household, with its internal network of legal and social support obligations, and part of the consideration of fairness involves a comparison between the households of each parent and their respective social as well as legal obligations (ie issues of corrective justice).

The child support formula barely resembles this vision of fairness. Nor, given judicial interpretation in cases such as Lyon $v$ Wilcox, do the departure rules.

\section{THE "REAL" FINANCIAL SITUATION}

In Lyon $v$ Wilcox, the Court of Appeal had little interest in taking into account all the social and economic facts. However, with the heavy emphasis on money, it might have been expected that judges would be keen to examine the liable parent's true financial position. Thus, it might have been thought, a parent should not be able to escape obligations by being able to rely on an artificially low return for income tax purposes. The experience under the child maintenance rules of the Family Proceedings Act 1980 was that the courts were in no way bound by tax returns but could look at the parties' financial situation in the round. Likewise, while the child support formula is built on assessable income, the departure order provisions free the courts from such restraints - or so it appeared until Andrews $v$ Andrews. ${ }^{54}$

In Andrews, the mother of three children had been receiving court ordered child maintenance at the level of $\$ 520$ per month, although the history of payment had been somewhat chequered. The father was a self-employed flooring contractor who was able to make a wide range of deductions in order to reduce his assessable income. The result of the child support assessment was that his obligations were reduced to the minimum amount of $\$ 10$ per week. The mother and children were forced out of their threebedroomed home and into a two-bedroomed flat. While the mother had a regular salary,

53 Mavis Maclean and John Eekelaar The Parental Obligation A Study of Parenthood across Households (Hart Publishing, Oxford, 1997) 39 [first emphasis added; second and third emphases in the original].

54 [1995] NZFLR 769. The High Court judgment is reported at [1994] NZFLR 39. 
her expenses outstripped her income and she was in a poor capital position. The father's capital position was much stronger and he was also able to employ his second wife in his business. Not surprisingly given the stringency of the ruling in Lyon $v$ Wilcox, the circumstances were not considered special enough for the new wife's income to be taken into account (even though there is an attractive argument that this was not the ordinary kind of situation for which the formula was designed, and in this sense is "special" or out of the ordinary).

The mother invoked the same provision as did the liable parent in Lyon $v$ Wilcox section 105(2)(c)(i) - to argue for a departure. Given the apparent injustice of using the formula and given the hardship facing the mother, one would expect the sympathies of any court to rest squarely with the mother. Such an expectation would however be misguided. The Family Court Judge and then Hammond J on appeal in the High Court held that the deductions made by the liable parent for tax purposes were entirely appropriate and should be carried over into the child support scheme. The court in considering a departure order could look at a parent's "real" financial position but only in rare situations, for instance where "unfair, or inappropriate devices have been adopted to diminish liability". ${ }^{55}$ The Trapski Committee which met around this time was not at all enamoured of the Hammond decision and indeed recommended that the formula be significantly amended to remove certain tax deductions from the child support calculations. ${ }^{56}$

The appeal to the Court of Appeal held out some hope for a more flexible standard. This hope too was dashed. The Court of Appeal refused to grant leave to appeal because it held that there was no question of law to determine. As Hammond J had allowed for the possibility of going behind the financial accounts to find the true income, he was held not to have made a mistake of law. The decision was then simply one on the facts. ${ }^{57}$ Despite this, the Court of Appeal accepted that the High Court Judge may have stated the law "too narrowly" and the Court of Appeal's own dicta belie the argument that it was merely determining the case on the facts: ${ }^{.8}$

In this case both Judges [in the courts below] agreed that the deductions were entirely appropriate and that was endorsed by the accountants' Statement of Accounting Policies in the accounts of the business for each of the relevant years. That was open on any view of the

\footnotetext{
55 [1994] NZFLR 39, 46.

56 The Trapski Report, above n 4, 77, recommendation 3 and para 6.1.

57 [1995] NZFLR 769, 771.

58 [1995] NZFLR 769, 771-772.
} 
correct approach. The matter was determined on the facts and there is no question of law

justifying leave on this point.

Now this, it is respectfully suggested, is where the Court of Appeal let the mother down - as a matter of law. Section 105(2)(c)(i) invites the court to consider "income, earning capacity, property, and financial resources" of the parents. As a matter of legal interpretation, it is not restricted to accounting policies. On the contrary, its purpose is to free the court from the rigidities of the child support formula in order to do justice in cases which are out of the ordinary. To apply section 105(2)(c)(i) correctly, it is surely essential to go beyond the regular accountancy practices, not merely in extreme cases of fraud or quasi-fraud. That is what the Courts in Andrews were not prepared to admit.

The overall result of Lyon $v$ Wilcox was to narrow the courts' ability to examine the social facts of a particular case. The overall result of Andrews was to narrow the enquiry into the parties' respective financial positions, so that, in most cases, crucial financial information can be ignored. Who is this "supporting"? Certainly not the children whose welfare ought, on good family law principles, to have been central to the determination, nor the mother struggling to bring up those children.

\section{CONCLUSION}

The authors have sought to illustrate that the Child Support Act is premised on unfortunately narrow concepts of parental and financial responsibility. They have shown that the interpretation of the Child Support Act by the courts has, with rare exceptions in cases such as those on step-parent declarations, also been unnecessarily narrow. The law and social reality have parted company.

Further, the best interests of the child have been ignored by the legislature and this can have a direct impact upon the child support situation. Although the State should not have to pay out millions of dollars per annum in benefits for sole parents without being able to recoup at least some of its expenditure, the cost of recovery may, in fact, wipe out much of the rationale underlying such a scheme. ${ }^{59}$ The rationale is also rendered problematic by the fact that the custodian more often than not does not see any of the child support because the custodian is on a benefit. This may act as a deterrent for both parents as the liable parent sees no advantage for the child, and the custodial parent sees no advantage in gaining an increase in child support.

$59 \$ 1136$ million paid in the year ending March 1990, with \$55 million recouped. The cost of administering the scheme was $\$ 27000$ 000: P R H Webb and others Butterworths Family Law in New Zealand (8 ed, 1997 Butterworths, Wellington, 1997) para 5200, page 327-328. 
The authors conclude that the child support law should be radically re-examined and the Trapski Report should be lifted off the shelves. The place of child support in an integrated family law system and the connections between access and child support should be part of this examination. Further, major socio-legal research is required to investigate whether the child support regime is genuinely effective in helping children and their caregivers. 